\title{
A MAGYAR JÖVŐKUTATÁS 50 ÉVE ÉS JÖVŐBELI IRÁNYAI
}

\section{YEARS OF FUTURES RESEARCH/STUDIES IN HUNGARY AND FUTURE DIRECTIONS}

\author{
Nováky Erzsébet \\ a közgazdaság-tudomány doktora, professor emerita \\ Budapesti Corvinus Egyetem Gazdaságföldrajz, Geoökonómia és Fenntartható Fejlődés Intézet Gazdaságföldrajz \\ és Jövőkutatás Központ \\ erzsebet.novaky@uni-corvinus.hu
}

\begin{abstract}
ÖSSZEFOGLALÁS
A tanulmány ötven év hazai jövőkutatási tevékenységét és tapasztalatait összegezve mutatja be az intézményes tudományos jövőkutatás főbb eredményeinek fejlődési ívét. Két korszakot különböztet meg: a jövőkutatás horizontális és vertikális kiépülésének időszakát és az instabil állapotok kezelésének időszakát. Az intézményes hazai jövőkutatás fejlődésében jelentős szerepet töltött be a Magyar Tudományos Akadémia IX. Osztályának keretében 1976 óta működő Jövőkutatási (2011 óta: Statisztikai és Jövőkutatási Tudományos) Bizottság. Jövőkutatóink lelkes csapata értékes publikációkkal, konferenciák szervezésével és színvonalas egyetemi szintű oktatással járultak hozzá az egyetemes jövőkutatási ismeret- és tudáshalmazhoz. Nemzetközi kapcsolatainkat erősítették a kutatási együttmüködések és a baráti kapcsolataink. A magyar jövőkutatók világosan látták, hogy alapvető jövőformáló szerepe a társadalmi innovációnak és az oktatásnak van, ezért mindent megtettek a tudományos kutatás és az oktatás mindenkori szerves kapcsolatáért.
\end{abstract}

\section{ABSTRACT}

Summarizing the preceding 50-year activities and experiences of Hungarian futures research/ studies, the article evaluates the development arch of main scientific results achieved by institutional scientific futures research/studies. The study distinguishes two periods: the era of horizontal and vertical development of futures research/studies, and the era of managing unstable matters. Since 1976 the Committee on Future Research operating within Section IX of the Hungarian Academy of Sciences (since 2011 Scientific Committee on Statistics and Futures Research) has played a substantial role in the institutional development of Hungarian futures

\footnotetext{
${ }^{1}$ A tanulmány Nováky Erzsébet „A magyar jövőkutatás történelmi léptékben” címü könyvfejezetének rövidített és átdolgozott változata. In: Nováky E. - S. Gubik A. (szerk.): A múltból átívelö jövő - VIII. Magyar (Jubileumi) Jövökutatási Konferencia. 50 éves a magyar jövőkutatás, 2018. Budapest, 2018. november 14-25. Konferenciakötet. Györ: Palatia Kiadó és Nyomda, 41-53.
} 
research/studies. The impassioned team of our futurists has greatly contributed to the knowledge base of futures research/studies by invaluable publications, organizing conferences and high-standard university education. Our international relationships have been strengthened by research collaborations and friendships. Hungarian futurists have clearly realized that social innovation and education actually have a fundamental future shaping role, hence they have been doing their best to constantly accomplish an efficient relationship between scientific research and education.

Kulcsszavak: intézményes jövőkutatás, foresight, káosz, jövőorientáltság, World Futures Studies Federation

Keywords: institutionalized futures research/studies, foresight, chaos, future orientation, World Futures Studies Federation

\section{A HAZAI INTÉZMÉNYES JÖVŐKUTATÁS KIALAKULÁSA}

Az intézményes jövőkutatás ötven éve, 1968-ban kezdődött hazánkban, ugyanabban az évben, mint amikor megalakult a Római Klub. Az 1960-as években megfigyelhető globális jelenségek - mint a világ népességszámának exponenciális növekedése, a meg nem újuló erőforrások kimerülésének gyorsuló üteme, a környezetszennyezés minden addigit meghaladó fokozódása - önmagukban is, de egymáshoz kapcsolódva még inkább a világ jövőjét jelentősen befolyásoló tényezőkké váltak. Nem lehetett megkerülni a velük való tudományos foglalkozást.

Az intézményes magyar jövőkutatás létrejöttét nemzetközi és hazai tényezők ösztönözték és segítették. A tudományos gyökerek már léteztek. A hazai jövökutatás épített az akkor negyvenéves prognosztikára és a huszonöt éves futurológiára. Oscar Morgenstern 1928-ban megjelent munkáját (Morgenstern, 1928) tekinthetjük a gazdasági prognosztika kezdetének. Ossip K. Flechtheim 1943-ban alkotta a futurológia szót, és rá két évre publikálta a jövővel való foglalkozás oktatásának fontosságát (Flechtheim, 1945). Az 1960-as években sorra jelentek meg a jövővel foglalkozó tudományos könyvek, tanulmányok, cikkek. A jövő felé irányultságot és érdeklődést fokozta az ezredforduló közelsége, hiszen kevés generáció élt meg ilyen jelentős fordulópontot. A jövő egyre „közelebb került” hozzánk.

Hazánk abban az időben szigorú tervgazdálkodási keretek között müködött. A rendszer müködésében fellépett zavarok a tervezés hatékonyságának fokozását sürgették, amelynek egyik módjaként a távlati tervek kidolgozásának igénye fogalmazódott meg. Az 1968-ban megkezdett új gazdasági mechanizmus - lazítva a tervutasításos gazdaságirányítás rendszerén - teret adott a hosszú távú, komplex, alternatívákban való gondolkodásnak. Kovács Géza egyetemi tanár felismerte a jövővel való tudományos foglalkozás és a történelmi pillanat jelentőségét. 
A hazai intézményes jövőkutatás nem előzmény nélküli. Az MTA Világgazdasági Kutatóintézetében folyó elemzési és előrejelzési munkák (Bognár József, Simai Mihály), a Szociológiai Kutatóintézetben a tudományos-technikai fejlődés kutatások (Farkas János), a demográfiai elemzések (Cseh-Szombathy László), az időmérleg-vizsgálatok (Szalai Sándor), a Tudományszervezési Csoportban folyó tudományfejlődési prognóziskészítési munkálatok tudományos hátteret nyújtottak az intézményes magyar jövőkutatás számára.

A magyar jövőkutatás kialakulásának folyamata nem volt problémamentes, rendszeresen kísérték a tudomány voltát megkérdőjelező támadások. A szocialista tervgazdálkodás körülményei között ugyanis nem volt létjogosultsága a polgári környezetből fakadó tudománynak. A marxista közgazdaságtani és az akkor uralkodó politikai szemléletmódtól idegen volt a jövőkutatás. Ez az ideológiai jellegű tényező sokáig elvi akadálya volt a jövőkutatás tudományként való elfogadásának, de minden akadályozó politikai tényező ellenére hazánkban is létrejött a modern értelemben vett jövőkutatás, és már a kezdeteket is pezsgő tudományos élet jellemezte.

\section{AZ INTÉZMÉNYES MAGYAR JÖVŐKUTATÁS SZAKASZAI}

A hazai jövőkutatás intézményes kereteinek kezdetét az 1968 szeptemberében a Marx Károly Közgazdaságtudományi Egyetem (MKKE) Népgazdaság Tervezése Tanszékén, Kovács Géza tanszékvezető egyetemi tanár által meghirdetett jövőkutatási kutató szeminárium jelentette. Ez képezte a jövőkutatás hazai egyetemi szintü oktatásának kiinduló alapját, kifejezve ezzel is a kutatás és az oktatás szerves egységét.

A hazai jövőkutatás ötvenéves periódusának első szakasza - a kezdetektől (1968) a rendszerváltásig (1990) - a jövőkutatás horizontális és vertikális kiépülésének időszaka volt. Sorra alakultak meg a jövőkutatás egyetemi és akadémiai mühelyei. A Kovács Géza által alapított Futurológia Csoport tekinthető a magyar jövőkutatás bölcsőjének, ahol a jövőkutatás komplex, nagy távlatú, futurológiai jellegü müvelése állt a középpontban. A prognosztikai ág müvelésére a Statisztikai Tanszéken megalakult Prognosztikai Kutatócsoport vállalkozott Besenyei Lajos vezetésével, a gazdasági előrejelzés módszertani kérdéseinek kutatása a Külkereskedelem Gazdaságtana Tanszéken, Korán Imre munkássága kapcsán került előtérbe. A Budapesti Müszaki Egyetem (BME) Filozófia Tanszékén Fodor Judit vezetésével a jövőkutatás filozófiai kérdéseit kutatták. A Semmelweis Orvostudományi Egyetemen (SOTE) a jövőkutatás elméleti és módszertani, valamint az egészségüggyel kapcsolatos kérdésköreit Gidai Erzsébet, a pécsi Janus Pannonius Tudományegyetemen (JPTE) a rövid távú prognosztika és a ciklusok kérdésköreit Sipos Béla tanulmányozta. Az MTA Tudományszervezési Csoportjában a 
jövőkutatás fogalmi-módszertani kérdéseit Szántó Lajos és Schmidt Ádám vezetésével kutatták, és hasznos jövőkutatási fogalomtárakat állítottak össze.

A kutatásokkal párhuzamosan megkezdődött a jövőkutatás elméleti-módszertani kérdésköreinek oktatása, és megjelentek az egyetemek specifikus jellemzöit tükröző jövőkutatási tantárgyak is, mint a Budapesti Közgazdaságtudományi Egyetemen a Nagy távlatú jövőkutatás, a Gazdasági prognosztika, az Üzleti prognosztika és kvantitatív előrejelzési módszerek tárgyak. A BME-n és a SOTE-n speciális kollégiumi választható tárgyként kezdődött a jövőkutatás oktatása, a JPTE-n Vállalati prognosztika címü tárgyat fejlesztettek ki.

A jövőkutatás második szakaszában, az 1990-es évekbeli hazai rendszerváltást követő változások - az instabil állapotok kezelésének időszakában - új helyzetbe hozták a jövőkutatást: számos tudományos kihívással szembesült, mint például az instabilitás kezelése, a bizonytalanság és a kiszámíthatatlanság erősödése, az egyén jövőt meghatározó szerepének növekedése, az értékváltások, amelyekre csak megújult jövőkutatási elmélettel-módszertannal lehetett válaszolni.

Megerősödött a jövőkutatás egyetemi bázisa: önálló Jövőkutatás Tanszék jött létre a Budapesti Corvinus Egyetemen (BCE) Nováky Erzsébet vezetésével, Üzleti Statisztikai és Előrejelzési Tanszék a Miskolci Egyetemen Besenyei Lajos vezetésével. Bővült az egyetemeken oktatott jövőkutatási tárgyak köre, és egyre több hallgató választotta a jövőkutatást TDK-dolgozat és szakdolgozat témájául is. A jövőkutatási tantárgyak megjelentek a PhD-képzésben is (Miskolcon, Pécsett, a BME-n). 2009-ben a BCE-n önálló Jövőkutatás alprogram indult, nyolctíz tantárggyal a Gazdaságinformatika Doktori Iskola keretében. Megerősödött a jövőkutatás nemzetközi dimenziója is, a BME-n az urbanisztikához kapcsolódóan, a BCE-n Business Futures Studies tantárgy oktatásával. BCE-hallgatók részt vettek a Turkui Egyetem Finland Futures Research Centre által szervezett nemzetközi távoktatási kurzusokon, ahol a Jövőkutatás Tanszék demonstrátorai és PhD-hallgatói 2005-től az oktatásban is részt vettek.

A 2010-es években bekövetkezett egyetemi strukturális változások közepette megtorpanni látszott a hazai jövőkutatás budapesti fejlődésének lendülete, ugyanakkor a jövőkutatás müvelése megerösödött a Miskolci Egyetem Gazdaságelméleti és Módszertani Intézetében. 2018-ban létrejött a Felelősen a Jövőért Virtuális Interdiszciplináris Kutatócsoport.

\section{AZ INTÉZMÉNYES MAGYAR JÖVŐKUTATÁS AKADÉMIAI KERETEK KÖZÖTT}

A hazai jövőkutatás eredményeit értékelve az MTA Gazdaság- és Jogtudományok Osztálya 1976-ban Jövőkutatási Bizottságot alapított Kovács Géza elnök vezetésével. Az MTA ezzel elismerte a magyar jövőkutatást önálló tudományként. A hazai jövőkutatók interdiszciplináris fórumaként müködő bizottság törekedett 
a különböző tudományterületeken elért eredmények szintetizálására, biztosította a hazai jövőkutatási konferenciák tudományos színvonalát, valamint két- és többoldalú nemzetközi kapcsolatokat épített ki.

A jövőkutatás akadémiai támogatottsága lényegileg nem változott annak következében, hogy az akadémiai intézményi struktúra átalakításának keretében a Jövőkutatási Bizottság fúzionált a Statisztikai Bizottsággal, és 2011 decemberében megalakult a Statisztikai és Jövőkutatási Tudományos Bizottság, amely két, önálló tudományág harmonikus, egymást kölcsönösen segítő kapcsolatát valósította meg.

Az akadémiai háttér mindvégig szilárd bázist jelentett a hazai jövőkutatás megerősödésében, és komoly támogatást nyújtott nemzetközi kutatásokban való részvételünkhöz. Ez utóbbiak közül csak néhányat emelünk ki: SusHouse Project, 1998-2000; Cost Action 22: Advancing Foresight Methodologies, 2004-2007; Prospective Technology Studies, 2001-2011, Karlsruhe; The AUGUR Project, 2009-2010; Millennium Project; Mobilising Corporate Foresight Potential among V4 Countries (FOR_V4), International Visegrad Fund, IVF.

\section{A MAGYAR JÖVŐKUTATÓK KIEMELT TUDOMÁNYOS EREDMÉNYEI}

A kezdeti elméleti-módszertani eredmények tisztázták a szocializmus viszonyai között a jövőkutatás kapcsolatát a tervezéshez, és helyét a tudományok rendszerében. A jövőkutatást a tervezés külső köreként definiáltuk: a jövőkutatás a lehetőségek feltárásával az alternatívák széles körét nyújtja a döntési elemet is magában foglaló tervezési munkához (Kovács, 1970). Értelmeztük a jövő megismerhetőségének, meghatározottságának, előrejelezhetőségének (Kristóf, 2006) és az alternativitásnak a kérdésköreit. A különböző időtávú ciklusok azonosítása és egymáshoz kapcsolása új tudományos eredményként jelent meg. A jövőkutatási módszerek rendszerezése (Besenyei et al., 1977) és hazai viszonyok közötti adaptálása (lásd például kölcsönhatás módszer) gyakorlati közelségbe hozta a jövőkutatást, amit az előrejelzések megbízhatóságának vizsgálata (Besenyei et al., 1982) tett teljessé.

A jövőkutatás módszertanának az instabil viszonyokhoz alkalmazkodó megújulása abban összegezhető, hogy a jövőkutatás egyszerre értelmezte a folyamatok dinamikáját és megváltoztathatóságát, valamint a társadalom szereplőinek a jövő alakítására irányuló törekvését, értelmezve a jövőformáló erőket. Egyértelmüvé tettük, hogy instabil viszonyok között nincsen lehetőség egyetlen, nagy valószínűséggel bíró jövőváltozat (azaz predikció) készítésére, hanem csak sok, többé-kevésbé azonos valószínüséggel bíró jövőváltozat feltárására. Megkérdőjeleződött a trendfüggőség, és utat engedett a trendtörések és a gyenge jelek vizsgálatának. 
Az instabilitás jövőkutatási kezelését a káoszelmélet alkalmazásában (Nováky, 1995) és az evolúciós fejlődés jövőkutatási specifikumainak feltárásában találtuk meg. A káoszelmélet segítségével elemeztük a föbb hazai makromutatók kaotikus viselkedését. Az evolúciós vizsgálatok a feltárható jövőmintázatok keresésében adtak újat. A metodológiai változások megjelentek az ágens modellek és a mesterséges neurális hálók használatában, érintették a konjunktúrakutatás eszközeit, a rövid és a hosszú távú csődelörejelzést. A forecasting és a foresight viszonyának értelmezése is ennek az időszaknak a terméke. Új témakörökként vizsgáltuk a big data és a jövőkutatás megbízhatóságának összefüggését, az IKT (információs és kommunikációs technológiák) és a hálózatosodás várható elterjedését és a kollektív tanulás folyamatát.

Definiáltuk a jövőorientáltság fogalmát és összetevőit. A magyar értelmezés nemzetközileg is elfogadottá vált (Nováky et al., 1994). Empirikusan vizsgáltuk a hazai lakosság jövőorientáltságát, keresve azokat a tényezőket, amelyek fokozhatják az egyéneknek a jövőhöz való pozitív viszonyát. A jövőorientáltság vizsgálatok hidat képeztek a múltból kibontható, ún. következmény jövők és a normatívan értelmezhető távolabbi jövőképek összekapcsolásában. A laikus egyén szerepének növekedése előtérbe hozta a participatív jövőkutatást, amelyhez kapcsolódott a kreativitás és az interaktivitás kérdésköre is.

A karakterisztikusan megjelent paradigmák (Hideg, 2012) - a pozitivista jövőkutatás mellett az evolúciós és a kritikai paradigmák, majd később az integrált jövőkutatás paradigmája - jelezték a különböző megközelítések és azok szintézisének lehetőségét és jelentőségét.

Magyar jövőkutatási tudományos eredményként könyveljük el a rendszeresen kidolgozott országos távlati, komplex jövőképeket. Az első hazai jövőkép az 1960-as évek végén készült, és 2000-ig tekintett elöre. A top $\rightarrow$ down megközelítésben készült előrejelzésben központi jelentőséget kapott a GDP alakulásának vizsgálata, a foglalkoztatási struktúra megváltozása és az oktatás-kutatás megnövekvő szerepe. A negyedik komplex hazai jövőkép a megújult jövőkutatás szemléletében készült, Magyarország 2025-beli állapotát vázolta fel 2007-ben az MTA IX. Osztály Jövőkutatási Bizottságának közreműködésével, különböző tudományterületek szakértőinek előrejelzéseire és nem szakértők véleményére támaszkodva (Nováky, 2010). Az alternatív forgatókönyvek és a jövőalternatívák kidolgozásához a jövőkutatás módszertani elveit - a komplexitás, a participativitás és az alternativitás elvét - alkalmaztuk. A jövőképben négy jövőalternatíva körvonalazódott, amelyek a nem szakértői reményekből és félelmekből épített négy alternatív forgatókönyvön alapulnak.

A tudományos alapon kidolgozott előrejelzéseink ágazati (például: közlekedés, számítástechnika, építőipar, biológia-világélelmezési válság) és regionális (például településfejlesztési) terveket is megalapoztak. Az ember mint bio-pszicho-szociális lény jövője és a magyar bünözés várható alakulása kutatás azért ér- 
demel kiemelést a társadalmi témák közül, mert a bünözés témakörét széles körü társadalmi és gazdasági környezetbe helyeztük, és az előrejelzést a jövőkutatási módszerek teljes skálájával készítettük el.

A hazai környezeti állapot elörejelzése már a jövőkutatás első szakaszában hangsúlyos szerepet kapott: interdiszciplináris kutatócsoport modulrendszerben kereste a társadalom, a gazdaság és a környezet jelenlegi és jövőbeli kapcsolatait, és ezekre építve jelezte előre hazánk várható környezeti állapotát (Nováky, 1991).

A hazai jövőkutatás második szakaszában a gyakorlatorientált előrejelzések elsősorban regionális stratégiák megalapozását szolgálták. A jövőkutatási eszközök - például egy speciális honlapfelület - használata újszerü eredményeket hozott a kis- és középvállalkozások jövőjének megfogalmazásában is.

A kutatási eredmények publikációkban öltöttek testet (lásd Kovács, 1999; Bóna, 1980; Hideg et al., 2014; továbbá a Magyar Tudományos Müvek Tára [MTMT] adatbázisa). Komoly hivatkozásokat elnyert tudományos cikkeink is megjelentek az MTA IX. Osztályának „listás” folyóirataiban. Az eredmények megtalálhatók a jövőkutatás témakörben rendezett tudományos konferenciák köteteiben is. A hazai országos jövőkutatási konferenciák megrendezésében ötven év alatt jelentős változás következett be. Az első jövőkutatási konferencia (1972) teljes hírzárlat mellett folyt, a későbbiekben lehetőség nyílt külföldi előadók meghívására is. A 7. (2008) és a 8. konferenciánkat (2018) az MTA IX. Osztálya a Magyar Tudomány Ünnepe rendezvénysorozat hivatalos osztályrendezvényének nyilvánította.

\section{A MAGYAR JÖVŐKUTATÁS NEMZETKÖZI KÖRNYEZETBEN}

Nemzetközi kapcsolataink a kezdeti években föleg a szocialista országokkal épültek ki, és a KGST (Kölcsönös Gazdasági Segítség Tanácsa) keretében (a Prognosztikai Munkabizottságban) rendezett konferenciákon és a fiatal kutatók számára rendezett nyári egyetemeken való részvételben teljesedtek ki.

Az 1980-as években már formálódtak kapcsolataink a World Futures Studies Federationnel (WFSF). Ez alapozta meg az 1987-es Európai Regionális Konferencia - Technology of Future and Its Social Implications - és két WFSF-világkonferencia (1990: Linking Present Decisions to Long-Range Visions, 2005: Futures Generation for Future Generations) hazai megrendezését. A BCE Jövőkutatás Tanszéke 1999-2005 között négy alkalommal rendezte meg a WFSF UNESCO támogatta nyári iskoláját (Budapest Futures Course: The Youth for a Less Selfish Future) a világ fiatal jövőkutatói számára.

A WFSF jelentősnek ítélte a világon elsőként összeállított tanulmánykötetet (Nováky et al., 2001) az európai volt szocialista országok jövőkutatási tevékenységének történetéről. 
A fentiek kisugárzó hatása nagyban növelte a magyar jövőkutatók nemzetközi elismertségét.

Nemzetközi jövőkutatási intézményekhez további formákban is kapcsolódtunk: a 2008-ban jogilag rendezett formában megalapított HuCoR (= Hungarian Club of Rome)-on, a Római Klub Magyar Szervezetén keresztül és 2013-ban a globális Millennium Projecthez kapcsolódva, megalapítva a Hungary Node-ot. Az együttmüködés keretében részt vettünk a State of Future vizsgálatokban és számos Real Delphi kutatásban.

\section{JÖVŐBELI IRÁNYOK ÉS FELADATOK}

Gazdag kutató- és oktatómunka áll a hazai jövőkutatók tudományos teljesítménye mögött. Munkánkat folytatni kell. Fejlesztendő a jövőkutatás tudománya és erősítendő a társtudományokkal való kapcsolata. Az új kihívásoknak megfelelően körvonalazandó hazánk társadalmi, gazdasági, technológiai és környezeti jövője. Növelni szükséges a magyar társadalom jövőformáló erejét, erősíteni különösen a fiatalok jövőhöz való pozitv viszonyát. Tudatosítani kell a távlatos, komplex szemlélet és a jövőkutatási módszerek használatának szükségességét a döntéselőkészítésben. Fokozni szükséges a jövőkutatási eredmények döntésalapozó szerepét és a jövőkutatási eredmények minél szélesebb körben való ismertté tételét és terjesztését, a gyakorlatba átültetését, és végül: a digitális eszközök használatát a kutatásban és az oktatásban egyaránt.

\section{IRODALOM}

Besenyei L. - Gidai E. - Nováky E. (1977): Jövőkutatás, elörejelzés a gyakorlatban. Módszertani kézikönyv. Budapest: Közgazdasági és Jogi Könyvkiadó

Besenyei L. - Gidai E. - Nováky E. (1982): Előrejelzés - Megbizhatóság - Valóság. Budapest: Közgazdasági és Jogi Könyvkiadó

Bóna E. (1980): Magyar jövőkutatási munkák. Bibliográfiai összeállítás hazai magyar szerzők jövőkutatási munkáiból 1979 végéig. Budapest: MTA Filozófiai Intézet

Flechtheim, O. (1945): Teaching the Future. Journal for Higher Education, 16, 460-465. DOI: $10.2307 / 1976978$

Fodor J. - Haraszthy Á. - Schmidt Á. (irányításával) (1976): Jövőkutatási fogalomtár. Budapest: Akadémiai Kiadó

Gidai E. (1990): Jövőalternatívák. A társadalmi-gazdasági fejlödés elörejelzésének lehetöségei. Budapest: Akadémiai Kiadó

Hideg É. (2012): Jövőkutatási paradigmák. Budapest: Aula Kiadó

Hideg É. - Nováky E. - Tóthné Szita K. (2014): A magyar jövőkutatás történeti alapjai. Jövőelméletek 20. Budapest: Budapesti Corvinus Egyetem, http://unipub.lib.uni-corvinus.hu/1668/1/ Jovoelmeletek_20.pdf 
Kovács G. (1970): Nagy távlatok és a tervezés. Budapest: Közgazdasági és Jogi Könyvkiadó

Kovács G. (1999): Jövőkutatás Magyarországon - múltja, jelene és jövő-alternatívái. In: Gidai E. - Nováky E. - Tóth A. (szerk.): Magyarország az ezredforduló után. Budapest: MTA Jövőkutatási Bizottság, 3-19.

Kristóf T. (2006): Is It Possible to Make Scientific Forecasts in Social Sciences? Futures, 38, 5, 561-574. DOI: 10.1016/j.futures.2005.09.004

Morgenstern, O. (1928): Wirtschaftsprognose - Eine Untersuchung ihrer Voraussetzungen und Möglichkeiten. Wien: Verl. von J. Springer

Nováky E. (ed.) (1991): Developing Environmental Strategies through Futures Research. Budapest: Ministry for Environmental and Regional Policy

Nováky E. (szerk.) (1995): Káosz és jövőkutatás. Budapest: Budapesti Közgazdaságtudományi Egyetem

Nováky E. (szerk.) (2010): Magyarország 2025. Tanulmánykötet. Budapest: Gazdasági és Szociális Tanács, http://unipub.lib.uni-corvinus.hu/1766/1/Mo 2025 1.pdf

Nováky E. - Hideg É. - Kappéter I. (1994): Future Orientation in Hungarian Society. Futures, 26, 7, 759-770. DOI: 10.1016/0016-3287(94)90043-4

Nováky E. - Ramba Varga, V. - Köszegi Kalas M. (eds.) (2001): Futures Studies in the European Ex-Socialist Countries. Budapest: Futures Studies Centre Budapest University of Economic Sciences and Public Administration, http://mek.oszk.hu/04000/04011/

Nováky E. - S. Gubik A. (szerk.) (2018): A múltból átívelö jövö. VIII. Magyar (Jubileumi) Jövökutatási Konferencia: 50 éves a magyar jövőkutatás, 2018. Budapest, 2018. november 14-15. Konferenciakötet. Győr: Palatia Kiadó és Nyomda. http://unipub.lib.uni-corvinus.hu/3786/ 